https://doi.org/10.18485/iipe_response2covid19.2021.ch27

\title{
BELARUS RESPONSE TO COVID-19: POLITICAL AND ECONOMIC ISSUES
}

\begin{abstract}
Asja Pentegova $^{1}$
Abstract: The coronavirus pandemic has clearly demonstrated the importance of regional cooperation and good neighbourliness. The initial politicization of the coronavirus topic is traced both in geopolitical and regional contexts. The "unique path" taken by Belarus faced severe criticism in spring 2020, while later nonlockdown strategies were adopted by many countries. In the wake of the global economic downturn, countries benefit from interregional economic cooperation and coordination in the framework of transnational logistics corridors. Austerity mode mobilizes the maximum possible efforts in the fight against the global pandemic and makes it rational to promote and share best practices. Strengthening humanitarian ties contributes to long-term cooperation and fuller implementation of the regional relations' potential. The proportionate involvement of Belarus in such mechanisms seems to be no-alternative and inevitable.
\end{abstract}

Keywords: Belarus, coronavirus pandemic, Europe, foreign policy, economic contacts, national interests, health system.

\section{INTRODUCTION}

The coronavirus pandemic has clearly demonstrated to the world community the importance of regional cooperation, good neighbourliness and mutual assistance in elaborating coordinated mechanisms to contain the spread of infection.

The pandemic and the systemic response to it have intensified the ongoing shifts in the global distribution of power. The international response to the pandemic has shown the lack of multinational cooperation, the relative ineffectiveness of multilateral organizations, and the tendency of states tackling the pandemic to pursue their own interests (Hrabina, 2021, 174).

${ }^{1}$ Advisor, Belarusian Institute for Strategic Research, Minsk, Belarus, pentegova@bisr.by. 
The coronavirus factor has catalyzed and improved international and domestic political processes. An important effect of this dynamic is a leadership vacuum to overcome global challenges, as well as increased competition and conflict between major players. As a result of the global force majeure, a significant portion of them became disoriented and unable to provide immediate and coordinated action.

One of the main lessons of the coronavirus era was the understanding that the survival of the most powerful European Union economies (Germany, Italy, France, etc.) could suddenly become directly dependent on health care systems. As a result of impulsive and radical severe measures (total lockdowns, emergency and quarantine regimes), a drop in GDP and a decrease in the number of employees in the second quarter of 2020 was the largest ever since the monitoring of the European statistical service Eurostat.

The COVID-19 pandemic marks a new geostrategic era in which biosafety and health security will take centre stage in national and international goals, policies, and actions.

The World Bank Group's COVID-19 reports and forecasts indicate a clear predominance of the risk of negative and poorly predictable development of the situation. In case of the vaccine and applied treatment inefficiency, further spread of infection across countries and the resumption of restrictive measures will place an even greater burden on consumption and investment (COVID-19 to Plunge Global Economy into Worst Recession since World War II, 2020). Such measures have already led to a massive impact on the economy, plunging it into a recession.

Pandemic fatigue can lead to underestimation of the growing threats by elites and experts and, consequently, to a decrease in control over the behaviour of the population. The first signs of this trend are already evident: the autumn aggravation in 2020 was characterized by a decrease in the barrier of fear of the population and protest activity against the introduction of severe restrictive measures in a number of European countries (the Czech Republic, Serbia, Germany, etc.).

\section{THE BELARUSIAN “UNIQUE PATH”}

Belarus had its first official case of COVID-19 registered on 27 February 2020 and its first death on 31 March 2020. At first, the increase in newly registered cases was slower than in most other countries, but at the beginning of April, the virus started to catch up.

We can trace the initial politicization of the coronavirus topic both in the geopolitical and regional context. The "unique path" taken by Belarus that was criticized in spring 2020 was subsequently adopted by the majority of countries, 
and the World Health Organization recommendations, which had thundered so much during the first wave about the need to tighten quarantine measures, are now safely forgotten. Among just a few countries in the world, Belarus did not introduce any kind of lockdown because of COVID-19. People went to their jobs, while schools, kindergartens and shops operated as usual.

Belarus has been under "media pressure" for almost the entire period of the pandemic. There were no medical reasons for criticism in the published articles. Belarusian doctors did not have to make a tough choice- who should live and who should die. It is due to the high level of the Belarusian healthcare system: senior medical students were mobilized to help, a number of institutions, along with medical staff and doctors, were re-purposed to treat COVID? 19 patients, and routine medical treatment was partly suspended. Today, the approach Belarus has tested has become the norm: despite the new waves of coronavirus, a vast majority of countries reject new lockdowns.

The activities of the Ministry of Health of the Republic of Belarus can be considered in two special dimensions: 1) horizontal, which concerns the coordination of activities with the competent republic institutions; 2 ) vertical, which refers to professional and material assistance to health care institutions (Terzic, 2021, 263-276).

Several interrelated factors were of crucial importance in the prevention and reduction of the possibility of contracting the COVID-19 virus in the territory of the Republic of Belarus:

1. the document Guidelines for the prevention of coronavirus infection (COVID-19);

2. the work method of the Ministry, which directed the activities of all entities involved in the prevention of the spread of the virus;

3. coordination of activities with the republic's institutions and harmonization of actions with measures of the Government of the Republic of Belarus;

4. consistent and continuous work on the maximum engagement of the capacities of all services and republic bodies.

At the regional level, Belarus, while advocating for multilateralism and foreign policy diversification, played an important role in coordinating joint efforts with Russia and the Eurasian Economic Union to contain the pandemic. At the same time, the development of regional cooperation is cycling when active contacts at the intergovernmental and interdepartmental levels and rather high indicators of cooperation are followed by periods of a decreased intensity of interaction. Constructive changes in interstate cooperation are not possible without maintaining and developing good-neighbourly relations between the countries. 
The Belarusian, Russian and Serbian military have been organising the Slavic Brotherhood Military Exercises since 2016. Despite the coronavirus pandemic, the Slavic Brotherhood Military Exercises were held in Belarus in September 2020. Probably due to the pressure of Western structures regarding the political crisis in Belarus, Serbia was cancelled on the eve of the already scheduled holding of the joint military exercise Slavic Brotherhood in Belarus in September, with the explanation that participation in all international military exercises is frozen for six months (Petrović, 2021, 13-14). For Belarus, Serbia's participation in regional integration projects in the Eurasian space is important. The long-standing partnership between the Eurasian Economic Union member states and Serbia has not been overshadowed by any serious political or economic differences. Over the years of the development of interstate relations, countries have reached a high level of cooperation based on the principle of mutual support and respect. They have many points of contact, including on international platforms.

The COVID-19 pandemic affects not only health but also the economy. The International Monetary Fund estimates World GDP growth in 2020 at as much as3.3\% (April 2021), but the Belarusian Statistics Committee says the GDP of Belarus in 2020 was down by $0.9 \%$ (January 2021). Many Belarusian industrial companies continued to produce products that were not sold and went to warehouses. The social effects of the pandemic and political crisis in Belarus seem to be rather controversial, which are not yet too significant but may manifest in 2021-2023 (COVID-19 and the Belarusian Economy: 4 issues, 2021). Belarusian businesses were forced to develop new forms of employment and ramp up digitalization, both of which will contribute to sustainability in the long run. But competition between players is intensifying everywhere.

After the arrival of the second and third waves of coronavirus, the recovery of the world economy is slowing down, and unemployment and regional trade and economic relations continue to stagnate.

The uncertain international situation related to the issue of the pandemic and the accompanying economic crisis are putting pressure on national resources as never before. Consequently, if the effectiveness of vaccines under development is proven and the rate of infection decreases, we can expect an unprecedented strengthening and development of regional supply chains.

In the wake of the global economic downturn, countries benefit from interregional economic cooperation and coordination in the framework of transnational logistics corridors. Belarus, as a country with a favourable geopolitical position, located between the West and the East, definitely should take the chance and use the available resources to become a full-fledged logistics corridor between the European Union and the Eurasian Economic Union. Potential areas of mutually 
beneficial cooperation include transport and logistics, mechanical engineering, construction, woodworking, pharmaceuticals, agricultural products, geology and mineral exploration, and the IT sector. It is important to attract investors to borderfree zones (for example, "Grodnoinvest") and create joint ventures there, and implement projects in the field of logistics. Despite the remaining challenges, including territorial debates, the Eurasian region clearly recreates the multi-polar regional architecture typical of today's world.

Based on the classification developed by Mark Khrustalev, a prominent Russian professor (MGIMO University of the Ministry for Foreign Affairs of the Russian Federation), three key vectors shaping the political and psychological aspects of relations between countries can be distinguished in the most general terms: "Friend-Enemy" Vector, "Dependence-Independence" Vector and "Trust-Distrust" Vector (Khrustalev, 2008).

After the elections in Belarus in August 2020, the relations between Belarus and the European Union can be attributed to the "Friend-Enemy" Vector: characterised by the highest degree of tension in the relationship as opposed to "fraternal relations", considered as the ultimate degree of friendliness. Nevertheless, the history and dynamics of our relationship have significant potential for growth. On the other hand, the relations between Belarus and Russia and the Eurasian Economic Union member states can be attributed to the "DependenceIndependence" Vector: based on the "balance of forces" between countries, or rather, on the obvious superiority of one international actor over another, where the second actor is explicitly dependent, both politically and economically, on the leading state. But in the last year, the Belarusian economic system has shown stability and has a high potential for self-sufficiency. The significant level of human development and education of the population should also be noted.

\section{THE MULTI-VECTOR PRINCIPLE IN BELARUS FOREIGN POLICY}

The Belarus foreign policy is based on preserving the sovereignty of the Belarusian state, equality of the participants of the integration projects and real benefits for the Belarusian state and the Belarusian people. The situation in Eastern Europe creates uncertainty in the regional security system. For Belarus, located between the geopolitical centres of power, it presents a serious challenge (Шадурский, 2016, 18).

Belarus implements the multi-vector principle in its foreign policy. The concept of multi-directionality as the foreign policy platform of the Republic of Belarus was developed in the second half of the 1990s and became a logical result of the strengthening of national sovereignty, although at this time active development of 
relations with Russia was more characteristic of the foreign policy of Belarus. At present, the significant partners for Belarus are primarily the neighbouring countries and the countries of Asia, Africa, and Latin America, constituting the so-called "far arc" of Belarusian foreign policy (Шадурский, 2010, 47-51). It is underlined that the main prerequisite for Belarus playing a more proactive role in the far arc regions was of political nature, and has to do with Minsk's chances of securing international support from the leaders of countries who share similar positions with regard to the existing world order. Simultaneously, one key priority for Belarus in the "far arc" countries is elated to the expansion of the markets for its products and attracting investments (Шадурский, 2019, 58-67).

For small and medium-sized ex-USSR countries, the choice of such a foreign policy model was almost the only means and option for development. Due to objective factors, the key players after the collapse of the USSR could not offer an adequate program of true partnership relations in the fields of economics, politics and security. In political science, a multi-vector foreign policy, as a rule, implies an independent foreign policy, the distinctive feature of which is to maintain balanced relations with key centres of power and the main regional players. Although science has not yet provided a clear and unambiguous definition of the multi-vector focus, discussions are continuing. Small and medium-sized countries are characterized by the principle of combining economic proximity with defence balancing in an effort to protect their sovereignty through reliance on other centres of power located beyond the integration core. The reason and logic behind such a policy is a civilizational factor that determines the need to develop mutually beneficial ties along the main vectors of the global geopolitical process - East and West, North and South (Стаховский \& Ярмолинский 2021, 43-48). Moreover, the principle of "pragmatism" and the strategy of balance are the basis of the foreign policy of Hungary, Slovakia, and Serbia. Belarus's cultural and humanitarian cooperation with the East and the West is an integral priority, and the country's need for the development of trust and good-neighbourly relations is a qualitative basis for constructive changes in interstate interaction.

And the political crisis that will erupt after August 2020 has only increased the demand for a multi-vector foreign policy, which is the only doctrinal approach that will allow Belarus to maintain its subjectivity in the face of the tumultuous regional and global agenda. Belarus has witnessed even more tragic periods in its history. The ability of the Belarusian people to adopt and use the achievements of others while preserving their own national identity, even under the most unfavourable conditions, is a valuable asset at the current stage (Шадурский 2000, 52-60).

This principle in Belarus's foreign policy is supported by sociological data. Based on a survey conducted in November-December 2020 by the Social and 
Humanitarian Research Centre of the Belarus State Economic University, half of the country's residents (52\%) believe the development of relations between Belarus and Europe can bring people together. On the other hand, polls conducted by the Institute of Sociology of the National Academy of Sciences of Belarus in OctoberNovember 2020 show that the majority (61\%) are positive about the creation of a Union State of Belarus and Russia (Стаховский \& Ярмолинский, 2021, 43-48).

The opportunity to establish the production of the Russian Sputnik V vaccine has been a weighty and substantial aspect of Belarus's economy and politics. This allows for activating domestic capacities, saving jobs, and avoiding dependence on foreign supplies. In Belarus, you can get vaccinated with a Russian or a Chinese vaccine (Ministry of health of the Republic of Belarus, 2021).

In addition, it should be noted that the ranking of values in Belarusian society changed in 2020-2021. A sociological survey conducted by the Center for Social and Humanitarian Studies of the Belarus State Economic University in NovemberDecember 2020 has shown that three values have remained unchanged over the past years: health, family, peace of mind, and comfort. (Table 1). However, for the first time, a major emphasis is placed on "health". Society is now such a powerful force in the world that governments will have to continue exploring new mechanisms and formats for engaging with it.

Table 1. Survey. "What is the most important thing in life?"

\begin{tabular}{|c|l|c|}
\hline No. & \multicolumn{1}{|c|}{ Values: } & Points \\
\hline 1 & Health & 4.7 \\
\hline 2 & Family & 4.6 \\
\hline 3 & Peace of mind and comfort & 4.5 \\
\hline 4 & Children & 4.4 \\
\hline 5 & Spouse, romantic partner & 4.4 \\
\hline 6 & Financially secure life & 4.3 \\
\hline 7 & Professionalism & 4.1 \\
\hline 8 & Exciting career & 4 \\
\hline 9 & Friends & 3.9 \\
\hline 10 & High position in society & 3.9 \\
\hline
\end{tabular}


For many years, the countries of Eastern and Southeastern Europe have been at the centre of the interests of the leading powers of the world. After the dissolution of the Socialist bloc, it was regional security and economic matters that made the centres of power keep their eyes on this area (Shishkina, 2020, 232).

Henry Kissinger, former US Secretary of State and National Security Advisor to Presidents Nixon and Ford, advises in The Wall Street Journal "to manage the crisis while building the future".

The periods of severe crises that we have all experienced and are going through today have always opened up new possibilities. Amid geopolitical and pandemic turbulence, there is a clear rising trend of regionalization, which can be regarded as a form of a new multi-vector approach. Belarus implements regional economic policies based on developing trade relations as well as on the support of emerging joint ventures and investment cooperation. Moreover, the growing self-sufficiency and complementarity of the economies spurs the process of regional integration and establishing powerful trade, economic and logistics networks. Creating the new logistics networks in the acute corona crisis period demonstrates the crucial role of regionalism as opposed to protectionism and economic downturn. The tendency to form regional trade platforms, which will exert considerable influence on the alignment of forces in world trade, is traced. The forming of integration blocks gives their participants the opportunity to solve arising problems on regional platforms. Moreover, regional engagement has provided a focus on themes of common interest in the regions, such as regional security, illegal immigration and other threats.

The pandemic and the accompanying economic crisis are putting pressure on national resources as never before. Since the austerity mode mobilizes the maximum possible efforts in the fight against the global pandemic, the most influential countries, world economic institutions, and aid funds should consider the possibility of directing funding to provide assistance to the health systems of small and medium-sized countries. The Belarusian flight crew transported humanitarian aid from China to the Serbian population. Subsequently, the Serbian Government sent two planes with medical supplies as humanitarian aid to Belarus (Pentegova, 2020, 65).

\section{CONCLUSION}

Vaccine protectionism endangers the global fight against COVID-19. Small and medium-sized countries are forced to manoeuvre between the centres of power to maximize the protection of their national interests. Subsidies aimed at reversing the economic downturn are clearly not going to produce the desired results 
overnight. At the same time, a decrease in the degree of passion, primarily at the regional level and in the vicinity, as well as a coordinated and well-considered public health policy, would give the economies a chance for a speedy recovery with minimal consequences.

According to the spring estimates of experts from the Leibniz Institute of Agrarian Development in Countries with Economies in Transition (Leibniz-Institut für Agrarentwicklung in Transformationsökonomien), we should not expect a complete and irrevocable victory over the coronavirus in the short run, especially if there are no natural changes in the nature of the virus. (It seems to be a realistic scenario in which up to $70 \%$ of the population could be infected.).

Humanitarian games in times of crisis and the fight for vaccines can have serious implications for regional cooperation. In the "political game" for the provision of humanitarian aid, there is a gradation depending on the foreign policy interests of specific countries, as a result of which there is lack of vaccination in a number of regions (for example, Africa). It should be noted that the selective provision of assistance in such a situation can heat unresolved conflicts and become a catalyst for the division of regions.

A fashion for mutual aid can offer a way out. Countries need to share best practices, overcome contradictions and mental shortcuts used for mutual evaluation. It is more rational to apply energy and resources to promote and share best treatment practices. Moreover, strengthening humanitarian ties will contribute to long-term interstate cooperation, as well as to the fuller implementation of the regional relations' potential. Thus, all countries need a common long-term strategy since neither the economy, nor the health care system, nor the population of each country can individually withstand the consequences of the crisis.

The proportionate involvement of Belarus in such mechanisms for sound participation in constructing a common post-crisis future seems to be no-alternative and inevitable. With the Russian Federation, the European Union, China, and the United States being the main players, the alignment and balance of power are largely determined by the strategies of regional middle-size states, which makes it important to have an appropriate national action plan aimed at domestic development insurance through new opportunities.

\section{REFERENCES}

COVID-19 and the Belarusian Economy: 4 issues (2021, March 03). retrieved from https://case-belarus.eu/covid-19-and-the-belarusian-economy-4-issues. Accessed 25 July 2021. 
COVID-19 to Plunge Global Economy into Worst Recession since World War II (2020, June 08), retrieved from https://www.worldbank.org/en/news/press-release/ 2020/06/08/covid-19-to-plunge-global-economy-into-worst-recession-sinceworld-war-ii Accessed 05 May 2021.

Eurostat. retrieved from https://ec.europa.eu/eurostat. Accessed 5 July 2021.

Hrabina, J. (2021). The year of crises: How 2020 will reshape the structure of international relations. Russia in Global Affairs, No. 1. pp. 174-199.

Khrustalev, M. A. (2008). Analysis of International Situations and Political Expertise. Moscow, Regional Library of International Relations.

Leibniz Institute of Agrarian Development in Countries with Economies in Transition. retrieved from https://www.iamo.de/. Accessed 18 May 2021.

Ministry of health of the Republic of Belarus. retrieved from http://minzdrav.gov.by/ ru/. Accessed 30 July 2021.

Pentegova, A. (2020). Political, economic and cultural cooperation between the Republic of Belarus and the Western Balkans through the lens of relations with Serbia. In: Bogdan Stojanović, Elena Georgievna Ponomareva (eds.) Russia and Serbia in the Contemporary World: bilateral relations, challenges and opportunities (pp 57-67). Belgrade, Institute of International Politics and Economics.

Petrović, D. (2021). The Perspective of Serbia's Cooperation with Russia and the Integration Processes Russia Is Leading in Eurasia. The Culture of Polis, Year XVIII, Issue 45. pp. 9-20.

Shishkina, O. (2020). Russia, the EU, and China: Foreign policy initiatives in Central, Eastern and South-Eastern Europe (CESEE). In: Bogdan Stojanović, Elena Georgievna Ponomareva (eds.) Russia and Serbia in the Contemporary World: bilateral relations, challenges and opportunities (pp. 231-245). Belgrade, Institute of International Politics and Economics.

Terzić, P. (2021). The Role of the Emergency Headquarters of the City of Kraljevo in the Fight Against COVID-19 Pandemic. The Culture of Polis, Year XVIII, Issue 45, pp. 263-276.

Стаховский, В. В., Ярмолинский, Ю. М. (2021). О новом формате многовекторности. [New multi-vectoral format]. Белорусская думка, №7. pp. 43-48.

Шадурский, В. Г. (2020). Внешняя культурная политика Республики Беларусь: состояние и проблемы. [Foreign Cultural Policy of the Republic of Belarus: the State and the Problems]. Белорусский журнал международного права и международных отношений, №. 4. pp. 52-60. 
Шадурский, В. Г. (2010). Реализация принципа многовекторности в белорусской внешней политике. [Realization of the Multi-vector Principle in Belarusian Foreign Policy]. Труды факультета международных отношений, научный сборник. Вып. 1. pp. 47-51.

Шадурский, В. Г. (2016). Политика Республики Беларусь в сфере безопасности: влияние внешних и внутренних факторов. [Policy of the Republic of Belarus in the Field of Security: Impact of Internal and External Factors]. Труды факультета международных отношений : науч. сборник / БГУ, Факультет международных отношений.- Вып. 7.- Минск : БГУ, рр. 13-19.

Шадурский, В .Г. (2019). Сотрудничество Беларуси со странами «Дальней дуги»: достижения и проблемы. [Cooperation of Belarus with the countries of "far arc": achievements and problems]. Беларусь в меняющемся мире: история и современность, материалы междунар. науч.-практ. конф., Минск, 22 февр. 2019 г. / Белорус. гос. ун-т ; редкол.: М. Э. Чесновский (пред.) [и др.]. - Минск : БГУ, 2019. pp. 58-67. 